\title{
MASSAGE UTILIZATION IN REDUCING POSTPARTUM MUSCLE TENSION
}

\author{
Arifah Istiqomah, Tuti Rohani, Suryo Ediyono \\ Midwifery Academy Ummy Khasanah, Yogyakarta
}

\begin{abstract}
Background: In the postpartum period, a mother experiences some physical and psychological changes. Some adjustment is needed by a woman to deal with her new role as a mother. The problems that often arise are fatigue after childbirth, tension due to contraction, poor blood circulation, migraine and headache, depression, breast milk dam, nipple blisters, insomnia, and baby blues. Prolonged fatigue may cause a negative effect of depression or postpartum blues. The purpose of this study was to examine the effect of massage treatment on postpartum muscle tension.

Subjects and Method: This was a randomized control trial conducted in Pleret, Bantul sub-district, Yogyakarta. A sample of 60 postpartum mothers was selected for this study and randomized into two groups. The dependent variable was muscle tension. The independent variable was massage. The data were collected by questionnaire and analyzed by Mann-Whitney test.

Results: Muscle tension in the control group (86.6\%) was higher than the treatment group (53.3\%) and it was statistically significant $(\mathrm{p}<0.001)$.

Conclusion: Massage is effective to reduce postpartum muscle tension.
\end{abstract}

Keywords: postpartum, massage, muscle tension

\section{Correspondence:}

Tuti Rohani. Midwifery Academy Ummy Khasanah, Jl. Pemuda, Bantul 55711, Yogyakarta. Email: rohani.tuti@yahoo.com.

Mid-International Conference in Public Health, Best Western Premiere Hotel, Solo, Indonesia, 18-19 April 2018 | 193 https://doi.org/10.26911/mid.icph.2018.03.29 